УДК $352.1+614.8$

\author{
Ткачук Роман, \\ E-mail: kars2004@ukr.net \\ ORCID iD 0000-0003-0556-7682

\section{УПРАВЛІННЯ ЦИВІЛЬНИМ ЗАХИСТОМ ЯК СКЛАДОВА МУНІЦИПАЛЬНОЇ БЕЗПЕКИ ВЕЛИКОГО МІСТА}

\author{
https://doi.org/10.32689/2618-0065-2021-2(8)-152-184
}

\begin{abstract}
Анотація. Стан захищенності кожного члена громади, власне сам захист від різних надзвичайних ситуацій, пожеж та небезпечних подій має
\end{abstract} безпосередній вплив на подальший соціально-економічний розвиток територіальної громади та зростання добробуту ії населення. У ході реформи місцевого самоврядування та територіальної організації влади в Україні значущі для безпеки населення повноваження передаються на найближчий до громадян базовий рівень влади - в територіальні громади. Рівень ризику в некомерційній муніципальній діяльності потребує чіткого усвідомлення керівництвом зростання очікувань з боку суспільного оточення та місцевих громад. Процеси децентралізації державного управління також висувають нові вимоги до муніципальної діяльності та збільшують відповідальність органів місцевого врядування за реалізацію ефективних змін. Прямування України шляхом дмократичних трансформацій вимагає партнерської співпраці між державою та місцевим самоврядуванням, спрямованим на подальший розвиток суспільства, його демократизацію, зміщення пріоритетів саме на громадянина, на забезпечення його потреб і реалізацію його прав, зокрема таких як право на безпечний оточуючий світ. Кодексом цивільного захисту визначено повноваження місцевої влади у сфері цивільного захисту, що спрямовані на розбудову відповідної територіальної підсистеми, реалізацію територіальних і місцевих програм із створення відповідних підсистем, спрямованих на захист населення і територій від надзвичайних ситуацій та запобігання їх виникненню, забезпечення техногенної та пожежної безпеки. Наразі з передачею низки повноважень у сфері цивільного захисту на місцевий рівень у керівників місцевих органів виконавчої влади має сформуватися розуміння того, що запобігання виникненню надзвичайних ситуацій на місцевому рівні та ліквідація їх наслідків є вимагає відповідної підготовки та планування заходів спільно 3 органами управління i підрозділами Державної служби України 3 надзвичайних ситуацій, а також відповідного розподілу бюджетних видатків на своєму рівні. Саме тому збереження безпеки міст, особливо великих, тягне за собою створення громадської інфраструктури для проведення заходів і впровадження технологій, які забезпечують захист громадян. 3 метою оптимізації структури виконавчого органу Київської міської ради (КМДА), а також забезпечення виконання завдань 3 питань оборонної 
роботи, цивільного захисту та взаємодії 3 правоохоронними органами затверджено структуру Департаменту муніципальної безпеки виконавчого органу Київської міської ради (КМДА), до складу якого включено Управління 3 питань цивільного захисту. Створення Департаменту муніципальної безпеки Київської міської державної адміністрації було обгрунтовано практикою реагування на НС на рівні міста, зважаючи на те, що функціонування виокремлених підрозділів на напрямами діяльності ускладнює взаємодію та координацію дій в умовах виникнення НС на місцевому рівні за рахунок витрат часу на узгодження заходів з реагування та розподілу наявних матеріально-технічних ресурсів.

Ключові слова: муніципальне управління, цивільний захист, надзвичайна ситуація, велике місто.

Постановка проблеми. Специфіка міста Києва полягає в тому, що воно $є$ великим містом із багатомільйонним населенням i розвиненою інфраструктурою у різних сферах економіки. На території міста розташовані об'єкти центральних органів виконавчої, законодавчої та судової влади, об’єкти критичної інфраструктури, заклади охорони здоров'я та освіти, спортивні i культурні заклади, місця 3 масовим постійним перебуванням громадян, величезні транспортні вузли, а також мости через Дніпро, що з’ єднують частини країни в єдине ціле.

Київ, який є не тільки найбільшим містом країни 3 більш ніж трьохмільйонним населенням, а й столицею України, потребує забезпечення техногенної, пожежної, екологічної, правоохоронної та антитерористичної безпеки, що наразі $\epsilon$ критично необхідним для нормальної життєдіяльності як самого великого міста так й його мешканців, дотримання їх законних прав, ефективного функціонування органів центральної та місцевої влади, економіки та міського господарства, транспорту і зв’язку, розвитку соціальної та духовної сфер суспільства.

Практичний багаторічний досвід реалізації завдань цивільного захисту міста Києва та забезпечення громадського правопорядку свідчить про нагальну потребу зміни парадигми, потребу врахування комплексності проблем безпеки великого міста та необхідність запровадження методів кризового менеджменту для управління безпековою сферою великого міста. 


\section{Науковий вісник : державне управління № 2(8) 2021}

Під час опрацювання джерел наукової інформації нами було визначено, що не зважаючи на використання терміну «безпека» та включення до назв підрозділів органів місцевого самоуправління, відсутнє будь-яке визначення цього.

Погодимось із думкою Л. Коженевского, що «безпека головна потреба окремої людини і суспільних груп, а також їхня найважливіша мета» [1].

Власне й грунтуючись на розумінні терміну «безпека» як стану захищенності індивідууму та суспільства від небезпек повсякденого життя і небезпек в умовах надзвичайних ситуацій будемо проводити подальше дослідження.

В. Пасічник в своїй статті [2], Д. Павлов своїй роботі [3] та Д. Тихомиров [4] висвітлили методологічні та міждисциплінарні підходи до формулювання терміну «безпека».

Спираючись на цю методологічну базу та результати аналізу функціоналу систем екстреного реагування на критичні або катастрофічні події на рівні адміністративної території, можемо запропонувати авторське визначення терміну «муніципальна безпека», а саме - комплекс заходів забезпечення безпеки (взаємодія з правоохоронними органами), цивільного захисту (реагування на аварії та надзвичайні події, взаємодія $з$ рятувальними службами, зокрема, співпраця 3 ДСНС України та ii територіальними підрозділами), територіальна оборона.

Зважаючи на комплексність явища «муніципальна безпека» в межах наукового дослідження накладено обмеження щодо дослідження управління цивільним захистом як складова муніципальної безпеки великого міста.

Аналіз останніх досліджень та публікацій. Дослідженню муніципальної політики як системи стратегічного управління самоврядною діяльністю присвячено дослідження українських вчених, що грунтуються на позитивних вітчизняних практиках та аналізі закордонного досвіду.

Автором у роботі [5] було здійснено переосмислення та обгрунтування підходів до розуміння підпорядкування, участі територіальних громад у розв'язанні місцевих проблем, досліджено принципи розподілу місцевих матеріальних і 
фінансових ресурсів й їх використання.

Перше фундаментальне дослідження методологічних засад муніципального менеджменту в Україні здійснено Ю. Шаровим [6], якій увів у вітчизняний науково-практичний обіг категорії «муніципальне утворення» та «муніципальний менеджмент», а у контексті забезпечення розвитку територій - категорії «керований розвиток», «стратегічне планування», «стратегія», «стратегічне мислення», «зона стратегічної відповідальності», «система технологій».

Генезу методології муніципального управління та його трансформацію в муніципальний менеджмент було докладно досліджено в роботі [7].

Проблематика інституційних, організаційних, правових та інших аспектів функціонування єдиної державної системи цивільного захисту, зокрема, вдосконалення механізмів державного управління та інституціональних аспектів діяльності державних систем цивільного захисту відображена в працях М. Андрієнка [8] та П. Волянського [9].

О. Бабаджанова [10] досліджувала нормативно-правове забезпечення органів місцевого самоврядування у сфері цивільного захисту 3 метою визначення кращих світових практик для удосконалення функціонування органів місцевого самоврядування в умовах реформи децентралізації для забезпечення даної функції. Саме за результатами аналізу світового досвіду розподілу владних повноважень на місцевому рівні автор зауважує на можливості передачі частини функцій у сфері цивільного захисту органам місцевого самоврядування.

Так, М. Кулєшовим в роботі [11] визначено, що підвищення готовності сил і засобів цивільного захисту до ліквідації наслідків застосування сучасних засобів ураження, НC природного та техногенного характеру та терористичних проявів $є$ одним з пріоритетних напрямів державної політики у сфері цивільного захисту на найближчий час. Для вирішення цієї проблеми необхідно підвищити готовність сил і засобів до дій за призначенням за рахунок перегляду та упорядкування існуючої структури і складу наявних сил цивільного захисту центральних i місцевих органів виконавчої влади, органів місцевого самоврядування відповідно до покладених на них 


\section{Науковий вісник : державне управління № 2(8) 2021}

завдань.

Проблематику функціонування системи цивільного захисту в умовах децентралізації було досліджено В. Костенком [12] та визначено, що при децентралізації влади та створення об'єднананих територіальних громад необхідні законодавчі та нормативні акти для регламентації заходів цивільного захисту на рівні територіальних громад.

I. Дробот та А. Рогуля у своїй роботі [13] зауважують на поступовій передачі повноважень щодо цивільного захисту в умовах децентралізації на місцевий рівень, що дозволить більш раціонально використати наявні інституціальні, фінасові i матерільні ресурси.

Рівень ризику в некомерційній муніципальній діяльності потребує чіткого усвідомлення керівництвом зростання очікувань 3 боку суспільного оточення та місцевих громад. Процеси децентралізації державного управління також висувають нові вимоги до муніципальної діяльності та збільшують відповідальність органів місцевого врядування за реалізацію ефективних змін.

Підсумовуючи, слід зауважити, що дослідження вчених досить детально охоплюють системи цивільного захисту багатьох країн світу (дослідження О. Труша, В. Тищенка, А. Рогулі) та України, проте проблеми функціонування органів управління заходами цивільного захисту міст, агломерацій та мегаполісів в доступній літературі вивчені недостатньо.

Методи дослідження. При проведенні аналізу джерел наукової інформації дотичних до досліджуваної проблеми було використано ретроспективний та критичний аналіз, при аналізі нормативних актів було застосовано контекстний аналіз. 3 метою дослідження оприлюдненості функції забезпечення муніципальної безпеки на рівні великого міста в мережі інтернет було використано інструменти контекстного пошуку за принципом релевантності.

Мета статті полягає у дослідженні управління цивільним захистом як складової муніципальної безпеки великого міста в умовах перенесення управлінських повноважень на місцевий рівень. 
Виклад основного матеріалу. Стан захищенності кожного члена громади, власне сам захист від різних надзвичайних ситуацій, пожеж та небезпечних подій має безпосередній вплив на подальше зростання добробуту населення об'єднаної територіальної громади. У ході реформи місцевого самоврядування та територіальної організації влади в Україні значущі для безпеки населення повноваження передаються на найближчий до громадян базовий рівень влади - в територіальні громади.

На думку директора Департаменту організації заходів цивільного захисту ДСНС Парталяна С. саме на рівні міських, селищних та сільських громад організовуються та реалізуються основні заходи захисту населення і територій. Тому кожна громада 3 перших днів свого існування має навчитися грунтовно планувати та організовувати свою безпеку, захист населення і територій від ймовірних надзвичайних ситуацій.

Передача більшості важливих для людей владних повноважень на рівень об'єднаної територіальної громади в умовах децентралізації вимагають розбудови прозорої та дієвоє системи місцевого самоврядування для забезпечення стабільного і безпечного життя громадян. Саме тому, на думку [14], одним із основних заходів реформування адміністративнотериторіального устрою країни є побудова системи захисту населення і територій від надзвичайних ситуацій (НC), здатної гарантувати безпеку людині.

Дослідниками [15-17] визначено, що огляд та аналіз найкращих практик здійснення стратегічного планування розвитку територіальних громад сприятиме забезпеченню якості підготовки управлінських рішень, посиленню їх ролі в процесі стратегічного планування, прийняттю різноманітних ефективних управлінських рішень в органах місцевого самоврядування в процесі стратегічного планування.

В умовах глобальних викликів необхідним постає подальше удосконалення механізмів стратегічного планування розвитку територіальних громад в Україні, що потребує нових наукових пошуків.

Для більшого розуміння досліджуваної проблеми слід ознайомитись 3 теоретичним базисом проблематики 


\section{Науковий вісник : державне управління № 2(8) 2021}

муніципального управління як виду соціального управління.

Важливим моментом $є$ розуміння самого терміну «державне управління».

Відповідно до визначення, наведеного в [18, с. 36-37], державне управління - «форма i різновид соціального управління, соціально-політична функція держави, зумовлена об'єктивними потребами суспільства, яка проявляється в цілеспрямованому, систематичному, ідеологічному, організаційному впливі з використанням владних повноважень на суспільну та приватну життєдіяльність 3 метою іiі впорядкування, збереження та переведення у якісно новий стан».

Виходячи 3 цього державне управління є невід'ємною складовою політичного управління, а саме $є$ процесом реалізації впливу виконавчо-владних державних повноважень відносно до будь-якої соціальної спільноти.

Важливою рисою соціального управління на відміну від державного управління $\epsilon$ те, що за умови вольового впливу одних суб'єктів на свідомість і волю інших, об'єктами впливу є соціальна організація суспільства [19].

На думку дослідників [20] до сфери соціального управління можна віднести діяльність політико-громадських об'єднань, поведінку окремих людей та груп, суспільну працю та економічну діяльність тощо.

Дослідниця I. Милосердна визначає політичне управління як вид соціального управління, що характеризується управлінським впливом суб'єктів на свідомість і волю інших, та відповідно об'єктами є політична організація суспільства 3 відповідними політичною структурою та соціальними процесами [21].

Базуючись на розглянутих дослідженнях та погоджуючись 3 думкою дослідників, що викладена в [22], визначаємо муніципальне управління як окремий вид політичного управління, де суб'єктом виступають територіальні громади.

В Україні місцеве самоврядування гарантується Конституцією, яка визначає місцеве самоврядування як самостійний рівень здійснення народом належної йому влади.

Існує багато визначень терміну «самоврядування». На нашу 
думку визначенням, що відображає функціонал цього явища $є$ наведене в [23] : «право, делеговане і гарантоване державою місцевим громадам (общинам, муніципалітетам) та іншим формам самоорганізації громадян, на незалежне і самостійне вирішення питань місцевого життя в межах чинного законодавства України та власної фінансово-економічної бази».

Відповідно до ст. 2 Закону України «Про місцеве самоврядування в Україні» місцеве самоврядування в Україні це гарантоване державою право та реальна здатність територіальної громади - жителів села чи добровільного об'єднання у сільську громаду жителів кількох сіл, селища, міста - самостійно або під відповідальність органів та посадових осіб місцевого самоврядування вирішувати питання місцевого значення в межах Конституції і законів України [24].

Згідно із Конституцією місцеве самоврядування є правом територіальної громади (жителів міста, селища та села чи добровільно об'єднаних у сільську громаду жителів кількох сіл) самостійно вирішувати питання місцевого значення в межах Конституції і законів України.

Відповідно до ст. 4 Закону України «Про місцеве самоврядування» місцеве самоврядування в Україні «здійснюється на принципах: народовладдя; законності; гласності; колегіальності; поєднання місцевих i державних інтересів; виборності; правової, організаційної та матеріальнофінансової самостійності в межах повноважень, визначених цим та іншими законами; підзвітності та відповідальності перед територіальними громадами їх органів та посадових осіб; державної підтримки та гарантії місцевого самоврядування; судового захисту прав місцевого самоврядування» [24].

Відповідно до ст. 16 Закону України «Про місцеве самоврядування» органи місцевого самоврядування $\epsilon$ юридичними особами і наділяються цим та іншими законами власними повноваженнями, в межах яких діють самостійно i несуть відповідальність за свою діяльність відповідно до закону.

Відповідно до ст. 10 Закону України «Про місцеве самоврядування» [24] визначено провідну роль виборних органів - місцевих рад, які по суті, виступають основним 


\section{Науковий вісник : державне управління № 2(8) 2021}

реалізатором муніципальної влади, що вирішують усі питання щодо задоволення місцевих інтересів і потреб місцевих жителів.

Наявність виборних органів місцевого самоврядування $\epsilon$ найважливішою умовою реальності й ефективності муніципальної влади. Ради є вторинним суб'єктом системи місцевого самоврядування, який підзвітний і підконтрольний своєму первинному суб'єктові - територіальній громаді [25].

Відповідно, місцеве самоврядування здійснюється за допомогою місцевих спільнот (територіальних громад), місцевих жителів, які зацікавлені в результатах місцевого управління, а не урядовими чиновниками при реалізації державно-владних повноважень на центральному рівні.

Дослідник Ю. Шаров в роботі [26] стверджує, що сутність децентралізації полягає в передачі на вирішення громадам або органам, які вони обирають, тих справ, урегулювання яких до певного часу належало державі. Важливим $\epsilon$ те, що повноваження та функції органів місцевого самоврядування мають бути направлені на вирішення питань, які стосуються інтересів населення відповідної адміністративно-територіальної одиниці, 3 урахуванням того, що не має бути дублювання відповідальності за окремі напрями та наявності факту відсутності відповідальності за інші напрями.

Фактично муніципальне управління, або як його іноді називають місцеве управління після державного $є$ другим рівнем управління, спрямованим організувати порядок i життєдіяльність спільнот більш дрібного масштабу, ніж держава, поселень або їх частин, районів міста.

Процеси децентралізації державного управління також висувають нові вимоги до муніципальної діяльності та збільшують відповідальність органів місцевого врядування за реалізацію ефективних змін [27]. Саме тому рівень ризику в некомерційній муніципальній діяльності потребує чіткого усвідомлення керівництвом зростання очікувань 3 боку суспільного оточення та місцевих громад щодо конкретних дій.

Забезпечення контрольованості та динамічності процесу формування політичних та економічних засад місцевого самоврядування відбувається в рамках Європейської Хартії 
місцевого самоврядування, яка встановлює шляхи його розвитку в сучасній Свропі за рахунок того, що питання, які можна вирішувати на низових рівнях управління, немає сенсу передавати на вищі рівні. Хартія зобов'язує держави, які іiі підписали, гарантувати і зміцнювати політичну, адміністративну та фінансову самостійність місцевих спільнот. Саме тому положення Свропейської Хартії місцевого самоврядування зорієнтовані на формування рамкових умов реалізації інструментарію муніципального менеджменту [28].

Взагалі, термін «муніципальний» можна перекласти 3 латинського як «такий, що взяв на себе тягар місцевих турбот» чи як «самоврядна громада». Саме «муніципальний» акцентує увагу на певних специфічних моментах самоврядування територіальної громади. У багатьох країнах Європи термін «муніципальний» застосовується для визначення рівня управління на рівні місцевого самоврядування. Певні розбіжності цього визначені в роботі [6], де зауважується на певні розбіжності в термінології в англомовних країнах де цей термін може відноситься тільки до міського самоврядування, у деяких інших - до всіх об'єктів місцевого самоврядування.

На думку Р. Махині [29] публічне управління у містахмегаполісах має розглядатись в контексті теорій великих систем і розвиватись з урахуванням теорії розвитку великих систем. Така система $є$ складною 3 двома елементами: самоорганізованою підсистемою та інтегрованою адміністративною підсистемою, яка має не виконавчу функцію, а законодавчу, що регламентує публічну владу, визначає межі іiі відповідальності та впливу на діяльність міст-мегаполісів. Ефективність такої системи досягається за допомогою відповідної організаційної роботи, спрямованої на створення ланцюгової реакції у всій системі, ефект від якої буде перевищувати ефекти в кожному окремому елементі системи i приводити до змін у всій системі в цілому і одночасно.

В. Орлов в роботі [30] зазначає, що реформа децентралізації розпочата у квітні 2014 року, надала більше можливостей територіальним громадам вирішувати питання місцевого значення. Одним 3 важливіших питань, яким почала 3 новою силою опікуватися територіальна громада - забезпечення 


\section{Науковий вісник : державне управління № 2(8) 2021}

правопорядку на території мешкання громади.

В. Терехов дослідив в роботі [31] міжнародний досвід особливостей, специфіки та структури відносин із взаємодії при забезпеченні безпеки на місцях. Узагальнено функції та напрямки безпекової політики органів місцевої влади, які здійснюються в США, Канаді, Великобританії, Сербії та Сінгапурі. Проаналізовано ефект від результатів впровадження технологій «розумне місто» в стратегію місцевої безпеки, проаналізовано досвід функціонування центрів безпеки та обгрунтовано доцільність їх створення в Україні.

Визначено I. Дем'янчуком в своїй роботі [32], що одним 3 основних напрямків процесу зміни систем управління та адміністративно-територіального устрою $є$ удосконалення єдиної державної системи цивільного захисту.

Відповідно до Закону України «Про місцеве самоврядування в Україні» управління містами нашої держави здійснюється територіальними громадами міст через відповідні міські ради та їх виконавчі органи. До делегованих повноважень виконавчих органів міських рад належить цивільний захист населення (ст. 36 «Повноваження в галузі оборонної роботи»).

Законом України «Про місцеве самоврядування в Україні» у п. 3 ст. 36 передбачено, що виконавчі органи міських ради організують та здійснюють заходи, пов'язані з мобілізаційною підготовкою та цивільним захистом на відповідній території. Об'єднання в одному пункті статті закону абсолютно різних за своїм значенням завдань призводить до суперечливості вимогам ст. 5 Закону України «Про мобілізаційну підготовку та мобілізацію», якою заборонено об’єднання мобілізаційних підрозділів з іншими структурними підрозділами органів влади та сумісництво працівників 3 питань мобілізаційної роботи, а також покладання на них функцій, які не пов'язані 3 розв'язанням поточних проблем мобілізаційної підготовки. Нажаль наявні непоодинокі приклади такого суміщення.

Проблематика реалізації функції держави у сфері цивільного захисту знайшла також своє відображення у Кодексі цивільного захисту.

Згідно $з$ п. 1 ст. 19 Кодексу цивільного захисту України [33] 
до повноважень місцевих державних адміністрацій у сфері цивільного захисту належить, зокрема:

забезпечення цивільного захисту на відповідній території; забезпечення виконання завдань створеними ними територіальними підсистемами та їх ланками; розроблення та забезпечення реалізації регіональних, місцевих програм та планів заходів у сфері цивільного захисту, зокрема спрямованих на захист населення i територій від надзвичайних ситуацій $(\mathrm{HC})$ та запобігання їх виникненню, забезпечення техногенної та пожежної безпеки;

керівництво створеними ними аварійно-рятувальними службами, формуваннями та спеціалізованими службами цивільного захисту, місцевою та добровільною пожежною охороною, забезпечення їх діяльності та здійснення контролю за готовністю до дій за призначенням;

створення за погодженням 3 центральним органом виконавчої влади, який забезпечує формування та реалізує державну політику у сфері цивільного захисту, та підтримання у постійній готовності територіальної системи централізованого оповіщення, здійснення її модернізації та забезпечення функціонування.

Закон України «Про місцеві державні адміністрації» [34] визначає організацію, повноваження та порядок діяльності місцевих державних адміністрацій.

Організація заходів цивільного захисту в територіальних підсистемах здійснюється місцевими державними адміністраціями.

Відповідно до Закону України «Про місцеві державні адміністрації» [34]:

місцева державна адміністрація $є$ місцевим органом виконавчої влади і входить до системи органів виконавчої влади;

місцева державна адміністрація в межах своїх повноважень здійснює виконавчу владу на території відповідної адміністративно-територіальної одиниці, а також реалізує повноваження, делеговані їй відповідною радою.

Окремим законодавчим актом врегульовано статус міста 


\section{Науковий вісник : державне управління № 2(8) 2021}

Києва як столиці України.

Відповідно до п. 2 ст. 1 Закону України «Про столицю України - місто-герой Київ» [35] місто Київ як столиця України $€$ : політичним та адміністративним центром держави;

місцем розташування резиденції глави держави Президента України, Верховної Ради України, Кабінету Міністрів України, Конституційного Суду України, Верховного Суду України, центральних органів державної влади.

Відповідно до норм цього Закону [35] :

ст. 6 визначає, що місцеве самоврядування у місті Києві здійснюється територіальною громадою міста як безпосередньо, так і через Київську міську раду, районні в місті ради (у разі їх утворення) та їх виконавчі органи.

ст. 10 визначає, що виконавчим органом Київської міської ради є Київська міська державна адміністрація (КМДА), яка паралельно виконує функції державної виконавчої влади, що $є$ особливістю здійснення виконавчої влади в місті Києві.

Розпорядженням КМДА від 25.05.1999 № 793 «Про територіальну підсистему єдиної державної системи запобігання і реагування на надзвичайні ситуації техногенного та природного характеру міста Києва» в місті створена i функціонує міська територіальна підсистема для запобігання i реагування на НС техногенного та природного характеру.

Регулюванням функції цивільного захисту щодо створення територіальної підсистеми стало затвердження рішенням IV сесії XXIV скликання Київської міської ради від 10.07.2003 № 616/776 Концепції безпеки міста Києва [36], яка є офіційно прийнятою системою поглядів на мету, завдання, основні принципи і напрямки діяльності у сфері забезпечення безпеки стійкого розвитку столиці, життя і здоров'я населення міста Києва, його прав та волі в умовах можливих загроз внутрішнього і зовнішнього характеру.

А також вона стала підставою для:

розробки стратегії забезпечення безпеки міста Києва;

удосконалення та подальшого розвитку нормативноправової бази забезпечення безпеки особистості, міста; 
розробки та реалізації цільових програм щодо забезпечення

безпеки столиці України від конкретних загроз.

Концепцією безпеки міста Києва було визначено інтереси міста у конкретних сферах прояву, зокрема $y$ сферi попередження та ліквідації НС техногенного $i$ природного характеру:

створення міської системи моніторингу та прогнозування $\mathrm{HC}$;

створення Київської міської служби порятунку;

удосконалення організаційно-правових основ функціонування міської територіальної підсистеми єдиної державної системи запобігання i реагування на НC техногенного та природного характеру;

підвищення ефективності діяльності щодо попередження виникнення НС, зменшення їх наслідків;

розвиток та підтримка у постійній готовності сил і засобів для ліквідації НС.

у техногенній сфері :

забезпечення безпеки виробничих структур, послідовна їх модернізація шляхом впровадження передових та нешкідливих технологій;

підвищення надійності роботи об'єктів та систем життєзабезпечення міста;

раціональне розміщення продуктивних сил міста;

забезпечення стійкого функціонування виробництв та інфраструктури міста Києва в умовах впливу факторів небезпек і загроз;

у екологічній сфері :

оздоровлення природного середовища, відновлення прийнятного рівня екологічного стану міста;

впровадження передових природоохоронних мір та технологій до генерального плану розвитку міста;

облік факторів захисту природи під час реалізації економічних та соціальних програм і проектів.

Відповідно до ст. 8 [37] територіальні підсистеми єдиної державної системи цивільного захисту створюються в Автономній Республіці Крим, областях, містах. Києві та Севастополі 3 метою здійснення заходів щодо захисту 


\section{Науковий вісник : державне управління № 2(8) 2021}

населення і територій від НС у мирний час та в особливий період у відповідному регіоні. Безпосереднє керівництво діяльністю територіальної підсистеми, іiі ланок здійснюється посадовою особою, яка очолює орган, що створив таку підсистему, ланку.

Для забезпечення цивільного захисту на відповідній території згідно 3 п. 1 ст. 19 Кодексу цивільного захисту України, постановою Кабінету Міністрів України від 09.01.2014 № 11 «Про затвердження Положення про єдину державну систему цивільного захисту», постановою Кабінету Міністрів України від 11.03.2015 № 101 «Про затвердження типових положень про функціональну і територіальну підсистеми єдиної державної системи цивільного захисту» голова місцевої державної адміністрації на початку року повинен видати розпорядження «Про створення ланки територіальної підсистеми єдиної державної системи цивільного захисту», затвердити «Положення про ланку територіальної підсистеми єдиної державної системи цивільного захисту».

Розпорядженням виконавчого органу Київської міської ради (КМДА) від 01.10.2015 № 988 відповідно до ст. 10 Кодексу цивільного захисту України, постанови Кабінету Міністрів України від 09.01.2014 № 11 «Про затвердження Положення про єдину державну систему цивільного захисту», постанови Кабінету Міністрів України від 11.03.2015 № 101 «Про затвердження типових положень про функціональну i територіальну підсистеми єдиної державної системи цивільного захисту», з метою здійснення заходів щодо захисту населення і територій від НС у мирний час та в особливий період у місті Києві затверджено Положення про територіальну підсистему міста Києва єдиної державної системи цивільного захисту (далі - Положення)[38], метою створення якої є захист населення i територій від НС у мирний час та в особливий період у місті Києві.

У цьому Положенні термін «територіальна підсистема міста Києва» вживається у значенні складової частини єдиної державної системи цивільного захисту, яка створюється у місті Києві і до якої входять районні ланки територіальної підсистеми, органи управління та підпорядковані їм сили 
цивільного захисту, відповідні суб'єкти господарювання, які виконують завдання цивільного захисту.

Положенням визначено завдання територіальної підсистеми міста Києва у сфері цивільного захисту, зокрема:

забезпечення готовності органів управління та підпорядкованих їм сил цивільного захисту до дій, спрямованих на запобігання i реагування на НC або небезпечні події;

проведення рятувальних та інших невідкладних робіт 3 ліквідації наслідків НС, організація життєзабезпечення постраждалого населення;

ліквідація наслідків НС або небезпечних подій;

проведення моніторингу і прогнозування НС та їх розвитку, визначення ризиків їх виникнення на території міста Києва, оцінка соціально-економічних наслідків НС, визначення на основі прогнозних даних обсягу потреби в силах, засобах, матеріальних та фінансових ресурсах;

ліквідація медико-санітарних наслідків НC та епідемій, надання екстреної медичної допомоги постраждалим у зоні $\mathrm{HC}$, здійснення заходів медичного забезпечення;

відповідно територіальна підсистема міста Києва складається $з$ районних ланок, що утворюються у районах міста Києва - районними в місті Києві державними адміністраціями.

Управління територіальною підсистемою цивільного захисту міста Києва відповідно до Положення здійснюють на: регіональному рівні - виконавчий орган Київської міської ради (Київська міська державна адміністрація), Департамент міського благоустрою та збереження природного середовища виконавчого органу Київської міської ради (Київської міської державної адміністрації) та Головне управління ДСНС України у місті Києві;

місцевому рівні - районні в місті Києві державні адміністрації, їх структурні підрозділи з питань цивільного захисту та районні управління Головного управління ДСНС України у місті Києві;

на об'єктовому рівні - керівник суб'єкта господарювання, а також підрозділи (посадові особи) 3 питань цивільного 


\section{Науковий вісник : державне управління № 2(8) 2021}

захисту, які призначаються відповідно до законодавства.

Згідно з ст. 23 Кодексу цивільного захисту [33] комунальні аварійно-рятувальні служби утворюються органами місцевого самоврядування у місті, районі міста, селищі, селі. Комунальні аварійно-рятувальні служби i аварійно-рятувальні служби громадських організацій, створені на професійній основі, $€$ юридичними особами.

Відповідно до п. 22 ч. 1 ст. 26 Закону України «Про місцеве самоврядування в Україні, та пункту 2.4 рішення Київради від 15.04.2004 № 157/1367 та для виконання заходів передбачених Концепцією безпеки міста Києва, в квітні 2004 року Київська міська рада затвердила рішення про створення комунальної аварійно-рятувальної служби «Київська служба порятунку» (www.usar-kiev.com.ua), а в травні цього ж року прийняла Міську цільову програму створення комунальної аварійнорятувальної служби «Київська служба порятунку» на 2004 2006 роки. Служба була зареєстрована як юридична особа 01.09.2004 p., а з 01.11.2003 р. почався набір особового складу служби. Мета діяльності служби - термінове реагування на НС техногенного та природного характеру, проведення попереджувальних, аварійно-рятувальних та відновлювальних робіт на об'єктах і територіях міста Києва. Штат комунальної аварійно-рятувальної служби «Київська служба порятунку» складає 107 одиниць, у т. ч. 94 одиниці оперативного складу [39].

Рішенням XI сесії VIII скликання Київської міської ради від 30.07.2020 № 256/9335 відповідно до ст. 90 Цивільного кодексу України, ст. 26, 54 Закону України «Про місцеве самоврядування в Україні», законів України «Про столицю України - місто-герой Київ», «Про державну реєстрацію юридичних осіб, фізичних осіб-підприємців та громадських формувань», рішення Київської міської ради від 20.06.2002 № 28/28 «Про утворення виконавчого органу Київської міської ради та затвердження його структури і загальної чисельності», 3 метою оптимізації структури виконавчого органу Київської міської ради (КМДА), а також забезпечення виконання завдань 3 питань оборонної роботи, цивільного захисту та взаємодії 3 правоохоронними органами затверджено структуру 
Департаменту муніципальної безпеки виконавчого органу Київської міської ради (КМДА), до складу якого включено Управління з питань цивільного захисту [40].

Наразі Департамент муніципальної безпеки КМДА, який було створено рішенням Київської міської ради від 30.07.2020 р., працює за напрямками безпеки, цивільного захисту та територіальної оборони, координує роботу комунальних підприємств «Київська служба порятунку» та «Муніципальна охорона». Основними напрямами роботи Департаменту є: безпека: взаємодія 3 правоохоронними органами; цивільний захист: реагування на аварії та надзвичайні події, взаємодія з рятувальними службами, зокрема, співпраця 3 ДСНС України та ії територіальними підрозділами, а також територіальна оборона: запобігати різним правопорушенням зусиллями представників.

Створення Департаменту муніципальної безпеки КМДА було обгрунтовано практикою реагування на НС на рівні міста, зважаючи на те, що функціонування виокремлених підрозділів на напрямами діяльності ускладнює взаємодію та координацію дій в умовах виникнення НС на місцевому рівні за рахунок витрат часу на узгодження заходів 3 реагування та розподілу наявних матеріально-технічних ресурсів.

За звітний період з 01.01.2020 по 31.12.2020 до комунальної аварійно-рятувальної служби «Київська служба порятунку» надійшло 387 звернень щодо надання допомоги громадянам, а саме: 136 викликів на НС, що сталися внаслідок погіршення метеорологічних погодних умов; 468 викликів на НС (надання доступу до постраждалих, транспортування важких хворих); 29 викликів на НС внаслідок дорожньо-транспортних пригод; 797 викликів на НС внаслідок наявності в навколишньому середовищі (забруднювальних) речовин понад ГДК; 139 викликів внаслідок пожеж; 121 виклик внаслідок раптового руйнування будівель та споруд (відкачка води, зняття аварійних конструкцій).

3 метою подальшої розбудови територіальної підсистеми єдиної державної системи цивільного захисту Києва рішенням Київської міської ради від 12.12.2019 №451/8024 було затверджено Міську цільову програму розвитку територіальної 


\section{Науковий вісник : державне управління № 2(8) 2021}

підсистеми єдиної державної системи цивільного захисту Києва на 2020-2022 роки. Міська цільова програма "Забезпечення готовності до дій за призначенням територіальної підсистеми міста Києва Єдиної державної системи цивільного захисту на 2020-2022 роки, що передбачає вирішення комплексу завдань щодо попередження виникнення та ліквідації НС техногенного й природного характеру.

Основні напрямки цільової програми:

створення та підтримання у постійній готовності територіальної системи централізованого оповіщення про $\mathrm{HC}$;

забезпечення матеріально-технічного переоснащення органів управління та комунальних служб;

будівництво нового пожежного депо; оновлення спеціальної пожежної техніки та обладнання у підрозділах пожежної охорони;

удосконалення системи підготовки фахівців 3 питань цивільного захисту, навчання населення діям в умовах надзвичайних ситуацій та в особливий період.

Слід зазначити, що концепція сучасного міста будується на забезпеченні комфортних умов життя населення за допомогою інноваційних технологій. Саме впровадження таких технологій дозволяє економічно та екологічно використовувати всі міські системи життєдіяльності.

Саме зміна поглядів на велике місто як джерело комплексних небезпек стала новим поштовхом розбудови системи цивільного захисту на рівні великого міста.

Основою систем сучасного міста $\epsilon$ ідеально працююча система безпеки, що інтегрована в інформаційно-аналітичний комплекс - Безпечне місто.

Проект «Безпечне місто» створений задля посилення безпеки киян, контролю роботи комунальних служб та управління трафіком у місті Києві. Вже зараз функціонує система розпізнавання обличь і номерів автомобілів.

Також відкрито три ситуаційні центри та налагоджена взаємодія 3 оперативними частинами МВС та СБУ. У майбутньому до системи планується підключити пожежну, рятувальну, медичну, дорожню й інші комунальні та державні 


\section{служби.}

ДСНС спільно з фахівцями Міністерства розвитку громад i територій України та Міністерства внутрішніх справ України відпрацьовано текст нової редакції Закону України «Про місцеве самоврядування в Україні» [41]. Зокрема у складі власних повноважень, які виконуються радою громади чи іiі виконавчим органом у обов'язковому порядку, визначено окремим блоком повноваження у сфері цивільного захисту (ч. 13 ст. 35 законопроекту).

На виконання Концепції реформування місцевого самоврядування та територіальної організації влади в Україні, ДСНС спільно 3 місцевими державними адміністраціями та органами місцевого самоврядування реалізовано пілотні проекти щодо удосконалення системи цивільного захисту та безпеки громад на базовому рівні місцевого самоврядування. За результатами реалізації цих пілотних проектів підготовлено низку методичних матеріалів, які містять рекомендації щодо утворення відповідних підрозділів з питань цивільного захисту, рішень та алгоритмів дій органів управління територіальних громад щодо реалізації повноважень у сфері цивільного захисту, аналіз реалізованих в громадах проектів, орієнтованих на безпеку життєдіяльності людини [42].

Практика функціонального підходу до забезпечення муніципальної безпеки великих міст наразі в Україні $\epsilon$ не досить поширеною. Лише два міста обласного значення Харків та Одеса, створили департаменти муніципальної безпеки, які покликані комплексно забезпечувати безпечні умови життєдіяльності мешканців великих міст.

Слід зауважити, що підрозділ 3 аналогічною назвою створено в складі Одеської міської державної адміністрації Департамент муніципальної безпеки Одеської міської ради серед яких:

розробка та організація виконання міських цільових та комплексних програм, спрямованих на забезпечення правопорядку, створення безпечних умов для життя, праці та відпочинку людей на території міста, захисту населення і території міста від НС та запобігання їх виникненню; організація та здійснення заходів цивільного захисту та 


\section{Науковий вісник : державне управління № 2(8) 2021}

запобігання виникненню НС на території міста;

контроль за виконанням заходів, пов'язаних із рятуванням життя i охороною здоров'я людей під час виникнення надзвичайних ситуацій на території міста Одеси, у тому числі на водних об'єктах.

У складі Харківської міської ради функціонує Департамент по взаємодії 3 правоохоронними органами та цивільного захисту, до складу якого входять комунальна установа «Спеціалізована водно-рятувальна служба міста Харкова» та комунальне підприємство «Муніципальна охорона». Відповідно завданнями департаменту є:

забезпечення взаємодії органів місцевого самоврядування міста 3 правоохоронними органами і військовими формуваннями, здійснення заходів, пов'язаних 3 оборонною, мобілізаційною роботою, а також забезпечення прав мешканців територіальної громади міста у сфері захисту населення та територій від НС техногенного та природного характеру;

реалізація державної політики у сфері оборони щодо організації та здійснення на території міста Харкова заходів, пов'язаних 3 мобілізаційною підготовкою, територіальною обороною та цивільною обороною (цивільним захистом) в умовах мирного часу та особливого періоду.

За результатами опрацювання офіційних сторінок міських державних адміністрацій міст 3 населенням більше 1 млн. мешканців нами встановлено, що переважна більшість мають виокремлені департаменти (управління) муніципальної варти, що опікуються забезпеченням громадського порядку i благоустрою, та департаменти (управління) цивільного захисту, завданням яких $є$ запобігання $\mathrm{HC}$ на місцевому рівні та реагування на них і взаємодія с територіальними підрозділами ДСНС України.

Грунтуючись на аналізі наукових розвідок [13, 42], присвячених дослідженню проблематики управління цивільним захистом в об’єднаних територіальних громадах, можемо стверджувати, що питання розбудови безпекового середовища великого міста науковцями розглядалося через призму 
функціонування органів управління і підрозділів ДСНС України, також досліджувалися питання покращання цивільного захисту та безпеки новостворених об'єднаних громад [43].

Спираючись на аналіз положень департаментів муніципальної безпеки у розрізі їх повноважень і функцій, а також з урахуванням практики муніципального управління $\epsilon$ можливим навести авторське визначення терміну «муніципальна безпека», а саме: муніципальна безпека - це комплекс заходів, спрямованих на забезпечення реалізації державної політики у сфері цивільного захисту на адміністративній території, здійснення заходів щодо охорони публічної безпеки та порядку, боротьби зі злочинністю та організацію і підтримку взаємодії з громадськими об'єднаннями щодо їх залучення до заходів, пов'язаних 3 підготовкою та веденням територіальної оборони.

Висновки та напрями подальшого дослідження. Наразі в Україні лише починає формуватися комплексний підхід до формування безпекового середовища великого міста через інтеграцію систем цивільного захисту, громадського правопорядку i територіальної оборони. Зміну світоглядів законодавців та управлінців спричинили не тільки необхідність завершення реформи децентралізації та розширення повноважень місцевої влади, а також нові виклики сьогодення, що змушують розлядати велике місто як потенційну мішень негативних впливів, і не тільки НС. Забезпечення безпеки розумних міст $\epsilon$ серйозною проблемою, так як в містах існує безліч загроз, включаючи тероризм, злочинність і стихійні лиха. Саме тому до головних пріоритетів у діяльності місцевих органів виконавчої влади віднесено запобігання виникненню НC техногенного та природного характеру та ефективна ліквідація їх наслідків НС.

Все вищевикладене, дозволило обгрунтувати авторське визначення терміну «муніципальна безпека», що об єднує безпекові складові великого міста, спрямовані на захист мешканця міста й всієї інфраструктури в цілому.

Грунтуючись на аналізі вітчизняного досвіду можна стверджувати, що розвиток безпечних розумних міст 


\section{Науковий вісник : державне управління № 2(8) 2021}

неможливо без співпраці держави і суспільства. Цю взаємодію певним чином ускладнює саме виключне державне регулювання цього питання та приватна власність значної частини міської інфраструктури.

Збереження безпеки міст тягне за собою створення громадської інфраструктури для проведення заходів i впровадження технологій, які забезпечують захист громадян. кроком до досягнення ситуаційної обізнаності. Для того щоб ефективно реагувати на виникаючі загрози, необхідно забезпечити співпрацю співробітників служб швидкого реагування, правоохоронних органів, а також урядових i громадських організацій.

Подальші наукові розвідки будуть зосередженні на дослідженні світових практик управління системою муніципальної безпеки та шляхів їх імплементації в Україні.

\section{Список використаних джерел}

1. Korzeniowski L. F. Securitologia - naukowe badania problematyki bezpieczeństwa człowieka i organizacji społecznych. Securitologia, №2 (16) 2012, s. 11-46.

2. Пасічник В. Філософська категорія безпеки як основа нової парадигми державного управління національною безпекою. Демократичне врядування : електрон. наук. фахове вид. 2011 Вип. 7. URL : http://nbuv.gov.ua/UJRN/DeVr_2011_7_7 (дата звернення: 16.03.2021).

3. Павлов Д., Микитюк М. Правові та організаційні засади забезпечення захисту критичної інфраструктури у контексті формування нової безпекової парадигми України. Честь і Закон. 2020. Т. 4. № 75. С. 69-77.

4. Тихомиров Д. Міждисциплінарні та філософські підходи до інтерпретації поняття «безпека». Юридичний часопис Національної академії внутрішніх справ. 2018. № 2(16). С. 104-115.

5. Шарий В. Сутність муніципальної політики як системи стратегічного управління самоврядною діяльністю. Вісник Національної академії державного управління при Президентові України. 2012. Вип. 4. С. 171177.

6. Шаров Ю. П. Стратегічне планування в муніципальному менеджменті: концептуальні аспекти. Київ: Вид-во УАДУ, 2001. 302 с.

7. Чикаренко I., Маматова Т. Розширення предметної сфери муніципального менеджменту. Аспекти публічного управління. 2019, 7 (1-2). С. 43-52.

8. Андрієнко М. В. Сфера пожежної безпеки в Україні: проблемні питання державного управління : монографія. Черкаси: видавець Чабаненко Ю. A., 2015. $288 \mathrm{c}$. 
9. Волянський П. Б., Гур'єв С. О., Соловйов О. С., Терент'єва А. В. Кризовий менеджмент і принципи управління ризиками в процесі ліквідації надзвичайних ситуацій / монографія.. К.: Парлам. вид-во, 2021. 432 с.

10. Бабаджанова О. Ф., Рогуля, А. О. Нормативно-правове забезпечення органів місцевого самоврядування у сфері цивільного захисту. Теорія та практика держсавного управління. 2018. Вип. 3. С. 146-153.

11. Кулєшов М. М., Росоха В. О. Сучасні виклики для державної політики у сфері цивільного захисту в Україні. Вісник НУЦЗУ, 2014. Вип.2. С. 167175.

12. Костенко В. О. Пріоритети удосконалення державного управління у сфері цивільного захисту територіальних громад в процесі децентралізації влади в Україні. Актуальні проблеми державного управління. 2017. 2(52). С. 97-103.

13. Рогуля А. О. Функції органів місцевого самоврядування в організації безпеки життєдіяльності територіальних громад України. Дис. ... канд. наук держ. упр. : 25.00.04 / Національна академія державного управління при Президентові України, Київ, 2019. 243 с.

14. Організація заходів цивільного захисту під час реформування місцевого самоврядування та територіальної організації влади в Україні. ДСНС України :

https://www.dsns.gov.ua/ua/Reformuvannya.html (дата звернення: 27.01.2021).

15. Заіченко І. В., Попова Ю. М. Управління розвитком територіальних громад. Перспективи розвитку територій: теорія і практика: матеріали Всеукраїнської науково-практичної конференції здобувачів вищої освіти i молодих учених, Харків, 19-20 листопада 2020 р. / Харківський національний університет міського господарства імені О. М.Бекетова, Рада молодих вчених при МОН України, Одеський національний економічний університет, НТУ «Дніпровська політехніка» [та ін.] Харків : ХНУМГ ім. О. М. Бекетова, 2020. С. 29-32.

16. Крайник O. Управління територіальною громадою в умовах децентралізації. Інноваційні інструменти забезпечення інвестиційного та інфраструктурного розвитку об'єднаних територіальних громад : матеріали наук.-практ. конф. за міжнар. участю, м. Дніпро, 27 листоп. 2020 р. / за заг. ред. І. А. Чикаренко. Дніпро : ДРІДУ НАДУ, 2020. С. 1317.

17. Пастух К. Стратегічне планування розвитку територіальних громад. Науковий вісник: державне управління. 2021. № 1(7). С. 195-215.

18. Публічне управління : термінол. слов. / уклад. : В. С. Куйбіда, М. М. Білинська, О. М. Петроє та ін. ; за заг. ред. В. С. Куйбіди, М. М. Білинської, О. М. Петроє. Київ : НАДУ, 2018. 224 с.

19. Малиновський В. Я. Державне управління: навчальний посібник. 3-те вид., перероб. та доп. К. : Атіка, 2009. 608 с.

20. Соціальне управління у контексті саморегуляції соціального організму країни: [монографія] / Володимир Бех, Юлія Бех, Сергій Попов ; [за наук 


\section{Науковий вісник : державне управління № 2(8) 2021}

. ред. д-ра філос. наук, проф. В. П. Беха]. Запоріжжя : Просвіта, 2012. $571 \mathrm{c}$.

21. Милосердна I. М. Зміст поняття "політичне управління". Правове життя сучасної України : матеріали Міжнар. наук. конф. проф.-викл. та аспірант. складу (м. Одеса, 16-17 травня 2013 р.) / відп. за вип. В. М. Дрьомін ; НУ "ОЮА". Півд. регіон. центр НАПрН України. Одеса : Фенікс, 2013. Т. 1. С. 236-238.

22. Нємець Л. М., Яковлєва Ю. К., Полевич І. О. Муніципальне управління: навчальний посібник для самостійної роботи студентів-магістрантів, які навчаються за спеціальністю «Економічна та соціальна географія». Харків, 2013. 75 с.

23. Старецька Л. І., Томнюк О. Є., Луценко 3. М., Юрченко М. М. Місцеве самоврядування: оглядовий курс. Навчальний посібник. К., 2006.78 с.

24. Про місцеве самоврядування в Україні : Закон України «від 21.05.1997 № 280/97-ВР // База даних “Законодавство України” / ВР України. URL:https://zakon.rada.gov.ua/laws/show/280/97\%D0\%B2\%D1\%80\#Text(дата звернення: 15.02.2021).

25. Закон про місцеве самоврядування: Науково-практичний коментар. К., $1999.396 \mathrm{c}$.

26. Шаров Ю. Актуальні проблеми муніципального розвитку: деякі результати досліджень. Зб. наук. пр. УАДУ при Президентові Украӥни. 2003. №2 (Вип. 2). С. 361-367.

27. Кухленко О. В., Гончарова Г. М., Кирилко Н. М. Управління змінами в муніципальній діяльності України. Фінансовий простір. 2017. № 1 (25). C. $43-47$.

28. Монастирський Г. Л. Адаптація муніципального управління в Україні до демократичних стандартів у контексті європейської інтеграції Aктуальні проблеми міжнародних відносин. 2014. Вип. 119 (ч. II). С. 15-22.

29. Махиня Р. А. Ефективність органів публічного управління містмегаполісів у контексті механізмів державного управління. Аспекти публічного управління. 2014. № 5-6. С. 28-34.

30. Орлов В. А. Муніципальна безпека: сучасні форми забезпечення. Конституційні принципи місцевого самоврядування та регіональна політика СС : Міжнародна науково-практична конференція: Харків, Україна. 2020. Т. 1. С. 72-76.

31. Терехов В. Міжнародний досвід взаємодії суб'єктів забезпечення муніципальної безпеки. Актуальні проблеми правознавства. 2017. №4(12). С. 139-144.

32. Демя'нчук I. Органи управління цивільним захистом населення великих міст: суміщення функцій. Актуальні проблеми державного управління. 2019. № 1(77). С. 35-38.

33. Кодекс цивільного захисту України : Закон України від 02.10.2012 p. № 5403-VI. // База даних “Законодавство України” / ВР України. URL:http://zakon1.rada.gov.ua/laws/show/5403-17 (дата звернення 24.11.2020). 
34. Про місцеві державні адміністрації : Закон України від 09.04.99 № 586XIV «// База даних “Законодавство України” / BP України. URL : https://zakon.rada.gov.ua/laws/show/586-14\#Text (дата звернення 18.02.2021).

35. Про столицю України - місто-герой Київ : Закон України від 15.01.1999 № 401-XIV// База даних “Законодавство України” / BP України. URL : https://zakon.rada.gov.ua/laws/show/401-14\#Text_(дата звернення 12.02.2021).

36. Про затвердження Концепції безпеки міста Києва : рішення IV сесії XXIV скликання Київської міської ради від 10.07.2003 № 616/776 // База даних «Законодавство України» / КМДА. URL : https://ips.ligazakon.net/document/MR030502 (дата звернення: 13.03.2021).

37. Про затвердження Положення про єдину державну систему цивільного захисту : постанова Кабінету Міністрів України від 09.01.2014 № 11 // База даних “Законодавство України” / BP України. URL: https://zakon.rada.gov.ua/laws/show/11-2014-п\#n10(дата звернення 24.11.2020).

38. Положення про територіальну підсистему міста Києва єдиної державної системи цивільного захисту : розпорядження виконавчого органу Київської міської ради (Київської міської державної адміністрації) від 01.10.2015 № 988 // База даних «Законодавство України» / КМДА. URL: http://kreschatic.kiev.ua/ua/5351/doc/1453479183.html (дата звернення: 15.03.2021).

39. Комунальна аварійно-рятувальна служба «Київська служба порятунку». КАРС «Комунальна служба порятунку» : офіційний веб-сайт. URL:http://www.usar-kiev.com.ua/pro-sluzhbu/ (дата звернення 19.03.2020).

40. Про зміну найменування Управління 3 питань цивільного захисту виконавчого органу Київської міської ради (Київської міської державної адміністрації) та деяких інших питань : рішення XI сесії VIII скликання Київської міської ради від 30.07.2020 № 256/9335 // База даних «Законодавство України» / КМДA. URL : https://kmr.ligazakon.net/document/mr200988\$2020_07_30 (дата звернення 15.03.2021).

41. Про місцеве самоврядування в Україні : Проєкт Закону України від 26.02.2021 № 9515. Законотворчість : база даних Верхов. Рада України. URL : http://komsamovr.rada.gov.ua/uploads/documents/42345.pdf (дата звернення 24.11.2020).

42. Дробот I. О. Модернізація державного управління системи цивільного захисту в об'єднаних територіальних громадах. Публічне врядування в Україні: стан, виклики та перспективи розвитку: матеріали щоріч. Всеукр. наук.-практ. конф. за міжнар. участю (Київ, 25 трав. 2018 р.) : у 5 ч. / за заг. ред. В.Куйбіди. Київ : НАДУ, 2017. Ч. 2 : Децентралізація публічного управління. С. 44-46.

43. Лещенко О. Я., Михайлов В. М., Романюк Н. М., Скакун В. О. Організація цивільного захисту під час реформування місцевого 


\section{Науковий вісник : державне управління № 2(8) 2021}

самоврядування та територіальної організаціївлади в Україні. : практичний порадник / за заг. редакцією М. О. Маюрова, П. Б. Волянського. Видання друге, доповнене. К. : ІДУЦЗ, 2017. 127 с.

\section{References}

1. Korzeniowski, L.F. (2012). Securitologia - naukowe badania problematyki bezpieczeństwa człowieka i organizacji społecznych. Securitologia, №2 (16), 11 - 46. ISSN 1898-4509 [in Polish].

2. Pasichnyk, V. (2011). Filosofska katehoriya bezpeky yak osnova novoyi paradyhmy derzhavnoho upravlinnya natsionalnoyu bezpekoyu [Philosophical category of security as the basis of a new paradigm of state management of national security]. Demokratychne vryaduvannya - Democratic governance, 7. Retrieved from http://nbuv.gov.ua/UJRN/DeVr 2011 7 7 [in Ukrainian].

3. Pavlov, D., Mykytyuk, M. (2020). Pravovi ta orhanizatsiyni zasady zabezpechennya zakhystu krytychnoyi infrastruktury u konteksti formuvannya novoyi bezpekovoyi paradyhmy Ukrayiny [Legal and organizational principles of critical infrastructure protection in the context of formation of a new security paradigm of Ukraine]. Chest $i$ Zakon - Honor and Law, 4, 75, 69-77 [in Ukraine].

4. Tykhomyrov, D. (2018). Mizhdystsyplinarni ta filosofski pidkhody do interpretatsiyi ponyattya «bezpeka» [Interdisciplinary and philosophical approaches to the interpretation of the concept of "security"]. Yurydychnyy chasopys Natsional'noyi akademiyi vnutrishnikh sprav - Legal Journal of the National Academy of Internal Affairs, 2(16), 104-115[in Ukrainian].

5. Shariy, V. (2012). Sutnist munitsypalnoyi polityky yak systemy stratehichnoho upravlinnya samovryadnoyu diyalnistyu [The essence of municipal policy as a system of strategic management of self-governing activities]. Zbirnyk naukovykh prats Ukrayinskoyi akademiyi derzhavnoho upravlinnya pry Prezydentovi Ukrayiny - Collection of scientific works of the Ukrainian Academy of Public Administration under the President of Ukraine, 4, 171-177 [in Ukraine].

6. Sharov, Yu.P. (2001). Stratehichne planuvannya v munitsypalnomu menedzhmenti: kontseptuani aspekty [Strategic planning in municipal management: conceptual aspects]. Kyiv: Ukrainian Academy of Public Administration under the President of Ukraine [in Ukrainian].

7. Chykarenko, I., Mamatova, T. (2019). Rozshyrennya predmetnoyi sfery munitsypalnoho menedzhmentu [Expansion of the subject area of municipal management]. Aspekty publichnoho upravlinnya - Aspects of public administration, 7 (1-2), 43-52[in Ukrainian].

8. Andriyenko, M.V. (2015). Sfera pozhezhnoyi bezpeky v Ukrayini: problemni pytannya derzhavnoho upravlinnya [Sphere of fire safety in Ukraine: problematic issues of public administration]. Cherkasy: vydavets Chabanenko Yu. A. [in Ukrainian].

9. Volyanskiy, P. B., Huriyev, S. O., Soloviyov, O. S., \& Terentieva, A. V. 


\section{Науковий вісник : державне управління № 2(8) 2021}

(2021). Kryzovyy menedzhment i pryntsypy upravlinnya ryzykamy v protsesi likvidatsiyi nadzvychaynykh sytuatsiy [Crisis management and principles of risk management in the process of emergency response]. Kyiv: Parlam. vyd-vo [in Ukrainian].

10. Babadzhanova O. F., Rohulya, A. O. (2018). Normatyvno-pravove zabezpechennya orhaniv mistsevoho samovryaduvannya u sferi tsyvilnoho zakhystu [Regulatory and legal support of local governments in the sphere of civil protection]. Teoriya ta praktyka derzhavnoho upravlinnya - Theory and practice of public administration, 3, 146-153 [in Ukrainian].

11. Kulyeshov, M. M., \& Rosokha, V. O. (2014). Suchasni vyklyky dlya derzhavnoyi polityky u sferi tsyvilnoho zakhystu v Ukrayini [Modern challenges for state policy in the sphere of civil protection in Ukraine]. Visnyk Natsionalnoho universytetu tsyvilnoho zakhystu Ukrayiny - Bulletin of the National University of Civil Protection of Ukraine, 2, 167-175 [in Ukrainian].

12. Kostenko, V. O. (2017). Priorytety udoskonalennya derzhavnoho upravlinnya u sferi tsyvilnoho zakhystu terytorialnykh hromad v protsesi detsentralizatsiyi vlady v Ukrayini [Priorities for improving public administration in the sphere of civil protection of territorial communities in the process of decentralization of power in Ukraine]. Aktualni problemy derzhavnoho upravlinnya - Actual problems of public administration, 2(52), 97-103 [in Ukrainian].

13. Rohulya, A. O. (2019). Funktsiyi orhaniv mistsevoho samovryaduvannya v orhanizatsiyi bezpeky zhyttyediyalnosti terytorialnykh hromad Ukrayiny [Functions of local self-government bodies in the organization of life safety of territorial communities of Ukraine]. Extended abstract of candidate's thesis. Kyiv: NAPA [in Ukrainian].

14. Sait Derzhavnoyi sluzhby Ukrayiny z nadzvychaynykh sytuatsiy [Site of SES of Ukraine]. www.dsns.gov.ua. Retrived from https://www.dsns.gov.ua/ua/Reformuvannya.html [in Ukraine].

15. Zaichenko I. V., Popova YU. M. (2020). Upravlinnya rozvytkom terytorialnykh hromad. Perspektyvy rozvytku terytoriy: teoriya i praktyka [Territorial community development management. Prospects for the development of territories: theory and practice]. Proceedings from MIIM'2020 : Vseukrayinska naukovo-praktychna konferentsiya zdobuvachiv vyshchoyi osvity i molodykh uchenykh - All-Ukrainian scientific-practical conference of applicants for higher education and young scientists (29-32). Kharkiv: Kharkiv National University of Municipal Economy named after O.M. Beketov [in Ukrainian].

16. Kraynyk, O. (2017). Upravlinnya terytorial'noyu hromadoyu v umovakh detsentralizatsiyi [Management of the territorial community in terms of decentralization]: Proceedings from MIIM'2020 : Mizhnarodna naukovopractychna konferentciia - The scientific-practical conf. for international participation (pp. 13-17). Dnipro: DRIPA NAPA [in Ukrainian].

17. Pastukh, K. (2021). Stratehichne planuvannya rozvytku terytorialnykh hromad [Strategic planning of territorial communities development]. Naukoviy visnyk: derzhavne upravlinnya - Scientific Bulletin: Public Administration, 1(7), 195- 


\section{Науковий вісник : державне управління № 2(8) 2021}

215 [in Ukrainian].

18. Kuybida, V. S., Bilynska, M. M. (Eds.). (2018). Publichne upravlinnya: terminolohichnyy slovnyk [Public administration: a glossary]. Kyiv : NAPA [in Ukrainian].

19. Malynovskiy, V.Ya. (2009). Derzhavne upravlinnya [Governance]. Kyiv : Attika [in Ukrainian].

20. Bekh, V., Bekh, Yu., \& Popov, S. (2012). Sotsialne upravlinnya u konteksti samorehulyatsiyi sotsialnoho orhanizmu krayiny [Social management in the context of self-regulation of the social organism of the country]. Zaporizhzhya : Prosvita [in Ukrainian].

21. Myloserdna, I.M. (2013). Zmist ponyattya "politychne upravlinnya" [The meaning of the concept of "political governance"]. Proceedings from MIIM'2013: Mizhnarodna koferenciia profesiynyih vykladachiv i aspirantskogo skladu "Pravove zhyttya suchasnoyi Ukrayiny" - The International Science conf. prof.-off and graduate student. composition "Legal life of Ukraine". (pp. 236-238). Odesa : Phenix [in Ukrainian].

22. Nyemets, L.M., Yakovlyeva, YU.K., \& Polevych I.O. (2013). Munitsypalne upravlinnya [Municipal administration]. Kharkiv [in Ukrainian].

23. Staretska, L.I., Tomnyuk, O.Ye., Lutsenko, Z.M., \& Yurchenko, M.M. (2006). Mistseve samovryaduvannya [Local Government]. Kyiv : N.p. [in Ukrainian].

24. Zakon Ukrayiny "Pro mistseve samovryaduvannya v Ukrayini" [About local self-government in Ukraine] : pryiniatyi 21 trav. 1997 roku № 280/97-BP (2021, February, 15). Retrieved from https://zakon.rada.gov.ua/laws/show/280/97-\%D0\%B2\%D1\%80\#Text(дата звернення: 15.02.2021) [in Ukrainian].

25. Zakon pro mistseve samovryaduvannya: Naukovo-praktychnyy komentar [Law on Local Self-Government: Scientific and Practical Commentary]. Kyiv: N.p. 1999. [in Ukrainian].

26. Sharov, Yu. (2003). Aktualni problemy munitsypalnoho rozvytku: deyaki rezultaty doslidzhen [Actual problems of municipal development: some research results]. Zbirnyk naukovykh prats Ukrayinskoyi akademiyi derzhavnoho upravlinnya pry Prezydentovi Ukrayiny - Collection of scientific works of the Ukrainian Academy of Public Administration under the President of Ukraine, 2(2), 361-367 [in Ukraine].

27. Kukhlenko, O. V., Honcharova, H. M., \& Kyrylko, N. M. (2017). Upravlinnya zminamy $\mathrm{v}$ munitsypalniy diyalnosti Ukrayiny [Management of changes in municipal activity of Ukraine]. Finansovyy prostir - Financial space, 1 (25), 43-47 [in Ukrainian].

28. Monastyrskiy, H. L. (2014). Adaptatsiya munitsypalnoho upravlinnya v Ukrayini do demokratychnykh standartiv u konteksti yevropeyskoyi intehratsiyi [Adaptation of municipal government in Ukraine to democratic standards in the context of European integration]. Aktualni problemy mizhnarodnykh vidnosyn - Current issues of international relations, 119 (II), 15-22 [in Ukrainian].

29. Makhynya, R. A. (2014). Efektyvnist orhaniv publichnoho upravlinnya mist- 


\section{Науковий вісник : державне управління № 2(8) 2021}

mehapolisiv u konteksti mekhanizmiv derzhavnoho upravlinnya [Efficiency of public administration bodies of megacities in the context of public administration mechanisms]. Aspekty publichnoho upravlinnya - Aspects of public administration, 5-6, 28-34 [in Ukrainian].

30. Orlov, V. A. (2020). Munitsypalna bezpeka: suchasni formy zabezpechennya [Municipal security: modern forms of security]. Proceedings from MIIM'20: Mizhnarodna naukovo-praktychna konferenciia "Konstytutsiyni pryntsypy mistsevoho samovryaduvannya ta rehionalna polityka YeS" - International Scientifical and Practical Conference "Constitutional principles of local selfgovernment and EU regional policy”. (pp. 72-76). Kharkiv [in Ukrainian].

31. Terekhov, V. (2017). Mizhnarodnyy dosvid vzayemodiyi subyektiv zabezpechennya munitsypalnoyi bezpeky [International experience of interaction of subjects of municipal security]. Aktualni problemy pravoznavstva - Actual problems of jurisprudence, 4(12), 139-144[in Ukrainian].

32. Demyanchuk, I. (2019). Orhany upravlinnya tsyvilnym zakhystom naselennya velykykh mist: sumishchennya funktsiy [Management bodies of civil protection of the population of large cities: combination of functions]. Aktualni problemy derzhavnoho upravlinnya - Actual problems of public administration, 1(77), 35-38 [in Ukrainian].

33. Kodeks tsyvilnoho zakhystu Ukrayiny [Code of Civil Protection of Ukraine]. (2012, October 2). Retrieved from URL:http://zakon1.rada.gov.ua/laws/show/5403-1 [in Ukrainian].

34. Zakon Ukrayiny "Pro mistsevi derzhavni administratsiyi" [About local state administrations]: pryiniatyi 9 kvit. 1999 № 586 (2020, November 25). Retrieved from http://zakon1.rada.gov.ua/cgi-bin/laws/main.cgi?nreg=58614[in Ukrainian].

35. Zakon Ukrayiny "Pro stolytsyu Ukrayiny - misto-heroy Kyiv" [About the capital of Ukraine - the hero city of Kyiv]: pryiniatyi 15 sichn. 1999 roku № 401-XIV. Retrieved from https://zakon.rada.gov.ua/laws/show/401-14\#Text[in Ukrainian].

36. Rishennya IV sesiyi XXIV sklykannya Kyivskoyi miskoyi rady "Pro zatverdzhennya Kontseptsiyi bezpeky mista Kyiva" [About the statement of the Concept of safety of the city of Kiyv] : pryiniatyi 10 lypn. 2003 roku. Retieved from https://ips.ligazakon.net/document/MR030502[in Ukrainian].

37. Postanova Kabinetu Ministriv Ukrayiny "Pro zatverdzhennya Polozhennya pro yedynu derzhavnu systemu tsyvilnoho zakhystu" [On approval of the Regulations on the unified state system of civil protection] : pryiniatyi 9 sichn. 2014 roku 09.01.2014 № 11. Retrievad from https://zakon.rada.gov.ua/laws/show/11-2014-ח\#n10[in Ukrainian].

38. Rozporyadzhennya vykonavchoho orhanu Kyivskoyi miskoyi rady (Kyivskoyi miskoyi derzhavnoyi administratsiyi) "Polozhennya pro terytorialnu pidsystemu mista Kyiva yedynoyi derzhavnoyi systemy tsyvilnoho zakhystu" [Regulations on the territorial subsystem of the city of Kyiv of the unified state system of civil protection] : pryiniatyi 1 zhovt. 2015 roku № 988. Retrieved 


\section{Науковий вісник : державне управління № 2(8) 2021}

from http://kreschatic.kiev.ua/ua/5351/doc/1453479183.html [in Ukrainian].

39. Sait sluzhby "Komunalna avariyno-ryatuvalna sluzhba "Kyivska sluzhba poryatunku" [Municipal Emergency Rescue Service "Kyiv Rescue Service"]. http://www.usar-kiev.com.ua. Retrieved from http://www.usarkiev.com.ua/pro-sluzhbu/ [in Ukrainian].

40. Rishennya XI sesiyi VIII sklykannya Kyivskoyi miskoyi rady "Pro zminu naymenuvannya Upravlinnya $\mathrm{z}$ pytan tsyvilnoho zakhystu vykonavchoho orhanu Kyivskoyi miskoyi rady (Kyivskoyi miskoyi derzhavnoyi administratsiyi) ta deyakykh inshykh pytan" [About change of the name of Department on questions of civil protection of executive body of the Kiyv city council (Kiyv city state administration) and some other questions]: pryiniatyi 30 lypn. 2020 roku № 256/9335. Retrieved from https://kmr.ligazakon.net/document/mr200988\$2020_07_30 [in Ukrainian].

41. Proyekt Zakonu Ukrayiny "Pro mistseve samovryaduvannya v Ukrayini" [Draft Law of Ukraine "On Local Self-Government in Ukraine"]: ryiniatyi 26 lyut. 2021 roku № 9515. Retrievad from http://komsamovr.rada.gov.ua/uploads/documents/42345.pdf[in Ukrainian].

42. Drobot, I. O. (2017). Modernizatsiya derzhavnoho upravlinnya systemy tsyvilnoho zakhystu $\mathrm{v}$ obyednanykh terytorialnykh hromadakh [Modernization of public administration of the civil protection system in the united territorial communities]. Proceedings from MIIM'17: Publichne vryaduvannya $\mathrm{v}$ Ukrayini: stan, vyklyky ta perspektyvy rozvytku: materialy shchorich naukovo-practychnoyi konferecii - All-Ukrainian scientific-practical conf. for international participation "Public governance in Ukraine: state, challenges and prospects of development" (pp. 44-46). Kyiv : NAPA [in Ukrainian].

43. Mayurov, M. O., Volyanskiy, P. B. (Eds.). (2017). Orhanizatsiya tsyvilnoho zakhystu pid chas reformuvannya mistsevoho samovryaduvannya ta terytorialnoyi orhanizatsiyi vlady v Ukrayini [Organization of civil protection during the reform of local self-government and territorial organization of power in Ukraine]. Kyiv: IPASCP [in Ukrainian]. 


\section{MANAGEMENT OF CIVIL PROTECTION AS A COMPONENT OF MUNICIPAL SECURITY OF A BIG CITY}

Tkachuk Roman

Abstract. Sustainable socio-economic development of the territorial community and the growth of the welfare of its population is impossible without addressing the safety of human life, its protection from various emergencies, fires and dangerous events. In the course of the reform of local self-government and territorial organization of power in Ukraine, powers important for the security of the population are transferred to the closest to the basic level of power - in territorial communities. It is at the level of urban, settlement and rural communities that the main measures for the protection of the population and territories are organized and implemented. Therefore, every community from the first days of its existence must learn to thoroughly plan and organize their security, protection of the population and territories from possible emergencies. In Ukraine, local self-government is being reformed and power is being decentralized, which involves the transfer of greater powers and resources to the level of territorial communities. The most important powers for people are transferred to the nearest level of government. In accordance with the requirements of current legislation, a simple and logical system of local self-government should be built, capable of ensuring a comfortable and safe life for citizens. Acceptable conditions of human life directly depend on the conditions of safe stay in the environment. Therefore, one of the main measures to reform the administrative-territorial structure of the country is to build a system of protection of the population and territories from emergencies, capable of guaranteeing human security. The level of risk in nonprofit municipal activities requires a clear understanding of management's growing expectations from the public environment and local communities. The processes of decentralization of public administration also set new requirements for municipal activities and increase the responsibility of local governments for the implementation of effective change. Local self-government is a characteristic feature of democratic development and is one of the most important elements of the relationship between state and society. The abstract opposition of state and local self-government in some theories is erroneous, world practice clearly demonstrates the inevitability of their coexistence and close interaction. Public administration and local self-government are institutions of society, each of which, performing its inherent functions, contributes to its overall formation and development. According to the Code of Civil Protection of Ukraine, the powers of local state administrations in the field of civil protection include, in particular: ensuring civil protection in the relevant territory; ensuring the implementation of tasks created by the territorial subsystems and their links; development and implementation of regional, local programs and action plans in the field of civil protection, in particular, aimed at protecting the population and territories from emergencies and preventing their occurrence, ensuring man-made and fire safety. Maintaining the security of cities entails the creation of public infrastructure for 


\section{Науковий вісник : державне управління № 2(8) 2021}

activities and the introduction of technologies that ensure the protection of citizens. Prevention of emergencies of man-made and natural nature, reduction of losses and losses in case of their occurrence and effective elimination of the consequences of emergencies is one of the main priorities in the activities of local executive bodies. In order to optimize the structure of the executive body of the Kyiv City Council (Kyiv City State Administration), as well as to ensure the implementation of tasks on defense, civil defense and cooperation with law enforcement agencies, the structure of the Municipal Security Department of the executive body of the Kyiv City Council (Kyiv City State Administration) was approved. which includes the Office of Civil Protection. The establishment of the Department of Municipal Security of the Kyiv City State Administration was justified by the practice of responding to emergencies at the city level, given that the functioning of separate units in the areas of activity complicates interaction and coordination of actions in emergencies at the local level. on response and distribution of available material and technical resources.

Key words: municipal government, civil protection, emergency, big city. 